\title{
Recreational fisheries in the USA: economics, management strategies, and ecological threats
}

\author{
Robert M. Hughes
}

Received: 21 June 2014/ Accepted: 29 September 2014/Published online: 28 October 2014

(C) Japanese Society of Fisheries Science 2014

\begin{abstract}
Recreational fishing has a long history in the USA, developing from the subsistence fisheries of Native Americans together with a partial subsistence fishery of later immigrants. Marine, diadromous, and aquatic taxa are targeted, including both vertebrates and macroinvertebrates. This paper defines recreational fishing, describes the main fishing techniques, identifies target taxa by region, summarizes the socio-economic values of recreational fishing, and discusses management strategies and major ecological threats.
\end{abstract}

Keywords Angling - Sport fishing - Outdoor recreation · Ecosystem services

\section{Introduction}

Recreational or sport fishing or angling is defined as fishing for pleasure, as opposed to commercial fishing for income or subsistence fishing for survival. Angling is typically conducted with a rod, reel and line with a baited hook, lure or fly attached. Some recreational fishing is conducted with a spear, net, or bow and arrows. In addition to finfish, recreational fishers collect crustaceans by net or trap, mollusks by hand, rake or shovel, frogs by spear or lures, and turtles by net. Fishing may occur from the shore of the water body, by wading in shallow waters, or from

This article publication is sponsored by the Japan Society for the Promotion of Science (JSPS) in a Grant-in-Aid for Publication of Scientific Research Results (KAKENHI 262003).

R. M. Hughes $(\bowtie)$

Amnis Opes Institute and Department of Fisheries and Wildlife, Oregon State University, 2895 SE Glenn, Corvallis, OR, USA

e-mail: hughes.bob@amnisopes.com watercraft ranging in size from large multi-passenger liveaboard ocean-going ships to single-passenger kayaks or float tubes. Most of the catch is consumed as food and it may be an important dietary component for some families, especially in rural areas where fishers have ready access to the potential catch. Increasingly, anglers are required by management regulations to practice catch-and-release fishing to conserve a fishery. Numerous finfish and shellfish species are recreationally fished in coastal waters (Appendices 1, 2, 3, 4) and many finfish species are recreationally fished in inland (fresh) waters (Appendices $5,6)$.

\section{Fishery catch and economics}

Recreational fishing is an economically and culturally important activity in the USA (Table 1). Based on national census data, an estimated 33 million anglers in 2011 participated in over 443,000 fishing trips and generated over $\$ 40$ billion in retail sales. Because of economic multiplier effects, these expenditures produced an estimated $\$ 115$ billion economic impact and over 800,000 jobs. Based on marine survey data, an estimated 12 million marine anglers took about 85,000 fishing trips in 2012 and spent nearly $\$ 31$ billion, which had an $\$ 82$ billion economic impact and provided 500,000 jobs. Although there are more freshwater anglers, marine anglers have a relatively greater economic impact because of the need for larger and more expensive gear and boats. In northern latitude USA states where recreational fishing is economically important, $14-43 \%$ of the population fishes, producing 10,000-38,000 jobs and a \$1.1-4.3 billion economic impact (Table 2). In two river basins in Idaho and Wyoming with high-quality catch-andrelease trout fisheries, 341-851 jobs and \$12-29 million in 
Table 1 Estimated economic impacts of USA recreational fisheries in 2011 (from ASA Web: http://asafishing.org/uploads/2011_ASAS portfishing_in_America_Report_January_2013.pdf, accessed April 2014; NMFS Web: http://www.nmfs.noaa.gov/stories/2013/04/docs/

\begin{tabular}{llllll}
\hline Data source & $\begin{array}{l}\text { No. of anglers } \\
\text { (million) }\end{array}$ & $\begin{array}{l}\text { No. of trips } \\
\text { (thousand) }\end{array}$ & $\begin{array}{l}\text { Direct sales } \\
\text { (\$ billion) }\end{array}$ & $\begin{array}{l}\text { Economic impact } \\
\text { (\$ billion) }\end{array}$ & $\begin{array}{l}\text { No. of jobs } \\
\text { (thousand) }\end{array}$ \\
\hline USFWS Web (US census) & 33.1 (marine and freshwater) & 443 (freshwater) & 41.8 & 115 (ASA Web) & 800 (ASA Web) \\
NMFS Web (marine surveys) & 12 & 85 & 31 & 82 & 500 \\
\hline
\end{tabular}

noaa_rec_fish_report_final_web.pdf, accessed April 2014; USFWS Web: http://www.doi.gov/news/pressreleases/upload/FWS-NationalPreliminary-Report-2011.pdf, accessed April 2013)
Table 2 Estimated economic impacts of state recreational fisheries in 2011 (ASA Web: http://asafishing.org/uploads/2011_ASASportfish ing_in_America_Report_January_2013.pdf, accessed April 2014)

\begin{tabular}{lllll}
\hline State & $\begin{array}{l}\text { No. of } \\
\text { anglers } \\
(\text { million })\end{array}$ & $\begin{array}{l}\text { Wages } \\
\text { (\$ billion) }\end{array}$ & $\begin{array}{l}\text { Economic } \\
\text { impact }(\$ \\
\text { billion) }\end{array}$ & $\begin{array}{l}\text { No. of jobs } \\
\text { (thousand) }\end{array}$ \\
\hline Alaska & 0.5 & 0.3 & 1.1 & 10 \\
Michigan & 1.7 & 1.4 & 4.3 & 38 \\
Minnesota & 1.6 & 1.3 & 4.1 & 36 \\
\hline
\end{tabular}

county income were created (https://henrysfork.org/files/ Completed\%20Research\%20Projects/Economic_Value_ of_Recreational_to_Communities-Loomis.pdf). Although this paper focuses on recreational fisheries, it is useful to compare them with the USA commercial seafood fisheries (including harvesting, processing, distributing, and sales); in 2012, that industry provided 1.3 million jobs and a $\$ 239$ billion economic impact (NMFS Web: http://www.st.nmfs.noaa.gov/ Assets/economics/documents/feus/2012/FEUS2012_National Overview.pdf, accessed June 2014).

Fishery catch data are collected from multiple sources and in multiple ways. Individual recreational catches of marine species are estimated through use of coastal telephone surveys, vessel telephone surveys, angler dockside surveys at ports, and state and regional logbooks (NMFS Web: http://www.st.nmfs.noaa.gov/Assets/ commercial/fus/fus12/03_recreational2012.pdf). The data gathered include number of trips, angler residency, species composition and catch rates, and species weights and lengths. The data are combined through use of models to produce catch, effort, and catch per unit effort metrics, which are reported by fish species, fishing method, state, and management region. Economic data for inland fisheries are obtained mostly from national census surveys of householders and state angler surveys. Canada relies on mail surveys of anglers every 5 years to estimate species-specific catch rates [1]. Oregon requires salmon, steelhead, and sturgeon anglers to purchase and complete a punch card for recording the species, number, location, and date of each of those species harvested (DFW Web: http://www.dfw.state.or.us/ resources/fishing/sportcatch.asp, accessed June 2014).

\section{Fisheries management}

Management agencies

In the USA, recreational fisheries are managed at both state and federal levels. State fish and wildlife agencies manage inland (freshwater) and near-coastal (within $5 \mathrm{~km}$ of the shoreline) fisheries. These agencies set and enforce fishing dates and times, fishing gear, and catch limits on fish size and number. The National Marine Fisheries Service manages marine fisheries outside the state management limits and regulates anadromous and marine species listed by the USA government as threatened or endangered. The US Fish and Wildlife Service regulates fisheries on listed freshwater species. The following fish species are listed as endangered or threatened by the federal government, thereby curtailing their fisheries: Alabama sturgeon Scaphirhynchus suttkusi, pallid sturgeon S. albus, Gulf sturgeon Acipenser oxyrinchus, shortnose sturgeon A. brevirostrum, bull trout Salvelinus confluentus, Apache trout Oncorhynchus apache, gila trout $O$. gilae; greenback cutthroat trout $O$. clarkii stomias, Lahontan cutthroat trout $O$. clarkii henshawi, Paiute cutthroat trout $O$. clarkii seleniris, black abalone Haliotis chracherodii, and white abalone $H$. sorenseni. Ecologically significant units of chum salmon $O$. keta, Chinook salmon $O$. tshawytscha, coho salmon $O$. kisutch, sockeye salmon $O$. nerka, steelhead (anadromous rainbow trout $O$. mykiss); golden trout $O$. mykiss aguabonita, and Pacific eulachon Thaleichthys pacificus are listed as threatened or endangered. The number of federally listed threatened and endangered fish species is strongly correlated with economic and population growth [2].

Although they do not manage fisheries, other federal resource management agencies have fisheries programs. Because their land and water management affects fisheries, the US Forest Service, Bureau of Land Management, National Park Service, US Geological Survey, Army Corps of Engineers, and US Environmental Protection Agency (USEPA) employ numerous fishery biologists. The USEPA has implemented a rigorous nationwide ecological monitoring and assessment program of surface waters (lakes, reservoirs, streams, rivers, near-coastal marine, wetlands). See Shapiro et al. [3] for an overview of the program, Paulsen et al. [4] and USEPA [5] for examples of stream 
and river assessments, and USEPA [6] for an example of a national lakes assessment.

Regulating recreational versus commercial fishing

Most conflicts involving relative take by recreational versus commercial fisheries occur in marine ecosystems. Total and relative catch limits in marine systems are set regionally by one of eight regional Fishery Management Councils established by the Fishery Conservation and Management Act of 1976: North Pacific, Pacific, Western Pacific, New England, Mid-Atlantic, South Atlantic, Gulf of Mexico, Caribbean. The voting members of each Council include one National Marine Fisheries Service representative, a representative from each State fishery agency in the Council region, private citizens nominated by State governors, and a representative from tribal or territorial governments in some regions (USFC Web: http:// www.fisherycouncils.org, accessed June 2014). Because each region supports different types of fisheries and different levels of commercial versus recreational fishing, there are no nationwide rules for decision-making. Differing levels and types of fishing are also affected by whether a species or stock is listed as overfished, vulnerable, threatened, or endangered, by its relative economic value to one type of fishery or another, and by previous take levels. For example, proposed options for allocating catch quotas between commercial and recreational fisheries on red snapper ranged from 51 and $49 \%$ to 0 and $100 \%$, respectively, with total catch baselines of 4-5 million $\mathrm{kg}$ (GMFMC Web: http://www.gulfcouncil.org/docs/amend ments/Amendment $\% 2028 \% 20-\% 20$ Allocation $\% 20 \mathrm{PH} \%$ 20Draft\%20March\%202014.pdf, accessed June 2014). In addition, if catches exceed established limits, a fishery may be closed for the season or it may be reduced in the subsequent year (GMFMC Web: http://www.gulfcouncil.org, accessed June 2014).

\section{Management funding}

Funding for state fishery agencies comes mostly from fishing license sales. In addition, federal excise taxes on fishing gear and boat fuels are dispersed to the states for fishery improvement projects (research, hatcheries, improved access, habitat rehabilitation). The enabling legislation for those taxes is the Dingell-Johnson Act of 1950 (Federal Aid in Sport Fish Restoration Act) and the Wallop-Breaux amendments of 1984. Between 1955 and 2006, those taxes yielded $\$ 36$ to $\$ 212$ million (in 2009 dollars) annually to the states (ASC Web: http://asafishing.org/uploads/Benefits_ to_Business_2011_Technical_Report.pdf, accessed April 2014).
The AFS and recreational fisheries management

The American Fisheries Society (AFS) is the premier society for professionals interested in fish, fisheries, and their ecosystems. Through its efforts, the US government established the US Commission for Fish and Fisheries in 1871 , with the requirement that it be led by a fish scientist. The 6,000-9,000 AFS members are employed by federal and state agencies, universities, private contracting firms, and nongovernmental agencies. Although most AFS members reside in the USA and Canada, there are chapters in Mexico and Puerto Rico and members are spread across the globe in 62 nations. As part of its mission, the AFS publishes books, a Fisheries magazine, and five scientific journals (Transactions of the American Fisheries Society; North American Journal of Fisheries Management; Marine and Coastal Fisheries: Dynamics, Management, and Ecosystem Science; Journal of Aquatic Animal Health; North American Journal of Aquaculture).

Perhaps the most popular AFS book is Inland Fisheries Management in North America [7]. That book's chapters describe techniques for managing stream, river, lake, and reservoir fisheries from individual stocks or populations to ecologically significant units or entire species through use of population dynamics [8]. The stock concept has been useful, both for maintaining healthy populations and for rehabilitating threatened populations of marine and freshwater fish. Three key fishery management techniques are regulating harvest [9], using hatchery fish to supplement populations [10], and enhancing the physical and chemical habitat [11]. Typically all three approaches are used in concert. Of course, quantitative data are needed before implementing such techniques, which require rigorous monitoring and assessment programs [12-14], including multistock and multispecies assessments [15].

\section{Threats to recreational fisheries}

\section{Historical and current threats}

Significant historical and current threats to USA recreational fisheries include intensified land use, physical habitat and hydrological modification, chemical contaminants, eutrophication and hypoxia, overfishing, and introductions of invasive non-native species (including hatchery fish) and diseases. In a study of over 9,000 European river sites, Schinegger et al. [16] reported disrupted connectivity (from dams and road crossings) in $85 \%$ of the catchments and $35 \%$ of the segments; $47 \%$ of the sites were altered by multiple factors and $90 \%$ of lowland rivers had altered water quality, hydrology, connectivity, and morphology. Similarly, in a survey of 1,900 
USA sites, USEPA [5] determined that 20-40\% of rivers and streams in the USA were in poor condition because of excess nutrients and disturbed riparian zones. In other words, multiple stressors frequently limit fish assemblages.

\section{Land use}

Land use, particularly intensive silviculture and agriculture, urbanization, and mining fundamentally alter the condition of surface waters, whether they occur in the USA or elsewhere. Mebane et al. [17] found that fish assemblage condition in large Oregon rivers declined with increased catchment agriculture and decreased catchment forest. Snyder et al. [18] reported poor conditions in fish assemblages once urban land use exceeded $7 \%$ in West Virginia catchments, especially with steeper channel slopes. Wang et al. [19] demonstrated that the percent of impervious area that was connected to streams negatively affected fish assemblages and trout densities in Minnesota and Wisconsin streams. Stranko et al. [20] reported brook trout almost never occurred in Maryland streams once catchment impervious cover exceeded $4 \%$. Trautwein et al. [21] reported that fish assemblage condition in Austrian streams declined with increased levels of catchment agriculture and urbanization and decreased levels of forest. In a series of western USA case studies, Woody et al. [22] summarized the negative effects of metal mining on salmonids. Daniel et al. (unpublished data, 2014) found that mineral and coal mining at the catchment scale had a greater effect on fish assemblages, including game species, than did that mining at the local scale and compared with catchment-scale urbanization or agriculture.

Catchment conditions may have a greater influence on fish assemblages than site conditions, whether they occur in the USA or elsewhere. Roth et al. [23] and Wang et al. [24] determined that catchment agriculture had a greater effect on fish assemblages in Michigan and Wisconsin streams, respectively, than did local riparian vegetation. Van Sickle et al. [25] found that the riparian conditions along Oregon stream networks explained more variability in fish assemblages than did conditions of the entire catchment or at the site. Sály et al. [26] demonstrated that variation in fish species and abundances in Rumanian streams was explained more by catchment and catchment-site shared variables than by site variables alone. For French streams, Marzin et al. [27] reported that anthropogenic variables at network riparian, catchment, shared site-riparian, or shared site-catchment scales explained more variation than sitescale anthropogenic variables. However, Macedo et al. [28] determined that site variables in Brazilian streams explained more variability in fish species richness than did catchment land use variables. For additional reading on landscape-scale effects on fish assemblages, see the books by Hughes et al. [29] and Yeakley et al. [30].

\section{Hydromorphological modification}

Physical and hydrological modification of fish habitat varies from major dams that fundamentally alter flows and convert rivers to lakes, to local changes in substrate and riparian vegetation. Stanford et al. [31] considered flow regulation the most pervasive change in large rivers, and Poff et al. [32] argued that flow regimes and flood pulses were master variables governing the condition of rivers. Based on studies of 27 large American rivers, Hughes et al. [33] reported that flow and channel alterations resulting from large dams were key factors disturbing fish assemblages. Carlisle et al. [34] determined that flows had been altered in 2,500 USA stream sites and that reduced flow magnitudes were better predictors of fish assemblage condition and impairment than site chemical or physical factors. Sedell and Froggatt [35] described how channelization and large wood removal from the Willamette River, Oregon, separated the channel from its floodplain and removed vast amounts of salmon spawning and rearing habitat. Similarly, in the eastern USA before European settlement, low gradient streams were anastomosing with extensive wetlands (hydromorphologically complex), rather than the single incised channels existing now [36].

\section{Substrate and riparian modification}

Lower fish assemblage condition was associated with excess fine sediments and reduced channel complexity at stream sites in the Oregon and Washington Coast Range [37]. Bryce et al. [38] concluded that surficial fine sediments $<5 \%$ were needed to maintain the habitat potential for trout and other sediment sensitive aquatic vertebrates in western USA mountain streams. Habitat simplification and loss of large wood debris in lakes of the midwestern and northeastern USA were associated with reduced game fish populations [39-42]. In a study of northeastern USA lakes, Kaufmann et al. [43] found that the richness of intolerant fish species was positively correlated with greater physical habitat quality, whereas the richness of tolerant fish species declined.

\section{Chemical contaminants}

Chemical contamination of USA waters has been reduced significantly since implementation of the Clean Water Act of 1972. Nonetheless, mercury concentrations exceeded the USEPA $300 \mathrm{ppb}$ fish tissue consumption criterion at nearly half of USA lakes [44]. In a survey of 600 western USA streams and rivers, Peterson et al. [45] 
found that large piscivorous game fish exceeded that mercury criterion in $57 \%$ of the assessed stream length. As a result of airborne chemical pollutants, even high elevation and high latitude lakes in national parks contain persistent pollutants that may place their fish and fisheries at risk [46].

\section{Eutrophication and hypoxia}

Despite effective nutrient removal from urban sewage, eutrophication remains a pervasive problem in USA waters, largely as a result of agricultural runoff. USEPA [5] reported that excess phosphorus was associated with poor fish assemblage condition in over $20 \%$ of the USA stream and river length. USEPA [6] found that $50 \%$ of USA lakes and reservoirs were eutrophic or hypereutrophic, with the highest proportions of eutrophic and hypereutrophic lakes in the agricultural central USA (36 and $24 \%$, respectively). When this nutrient rich runoff reaches near-coastal marine waters, it produces ocean hypoxia. For example, a $20,000 \mathrm{~km}^{2}$ hypoxic area exists in the Gulf of Mexico as a result of nitrogen and phosphorus from the Mississippi River Basin [47]. Along the USA East Coast, agricultural runoff has led to coastal marine eutrophication [48]. Nationally, Dodds et al. [49] estimated that eutrophication creates over $\$ 2$ billion in damages annually.

\section{Overfishing}

Recreational overfishing has been a historical issue for many highly valued species (e.g., GMFMC Web: http:// www.gulfcouncil.org, accessed June 2014) but its impacts have been reduced by fishery management agencies, and recreational fishing typically has markedly less impact than commercial fishing. Nonetheless, as any angler can attest, additional fishing does not improve one's chances of catching fish or the fishing experience.

\section{Non-native fish}

By sampling 1,000 western USA stream and river sites (representing 90,000 stream kilometers), Lomnicky et al. [50] estimated that $52 \%$ of the stream length contained non-native aquatic vertebrates (83\% of large river length). Three different trout were the most commonly occurring non-native species. Sanderson et al. [51] estimated that the effects of non-native species on Pacific salmonids equalled or exceeded that of hatcheries, harvest, hydropower and habitat degradation. In addition to non-native fish, hatchery fish stray onto spawning grounds, diluting the genetic pool of wild salmonids, and increase feeding competition in freshwater [52-56], in estuaries, and at sea [57-60]. Such changes limit the recovery of listed wild salmonids.
Developing threats to USA recreational fisheries

Significant developing threats to USA recreational fisheries include endocrine disrupters, nanoparticles, and climate change. All three are pervasive and threaten freshwater and marine recreational fisheries.

\section{Endocrine disrupting chemicals}

For years, we have known about the presence of endocrine disrupting chemicals in aquatic environments, as well as their physiological effects on fish and other aquatic vertebrates [61-63]. Recently, their potential population-level effects in natural environments have been modelled quantitatively [64], as have their management implications [65]. Because of the number of such chemicals in the environment and their developmental and immunological toxicity at very low levels, they are considered a ticking time bomb [66].

\section{Nanoparticles}

The physico-chemical effects of nanoparticles on fish populations are at an early stage of understanding [67], but their rapidly increasing use and widespread distribution are troubling. Shaw and Handy [68] reported that nanocopper was twice as toxic as dissolved copper and that nanoparticles altered respiration and caused gill, liver, intestine and brain tissue pathology. Cedervall et al. [69] found that nanopolystyrene passed up the algae-zooplankton-fish food chain and altered lipid metabolism and halved food consumption rates of fish.

\section{Climate change}

Climate change is predicted to have substantial impacts on USA marine and freshwater recreational fisheries. By 2100, ten states are predicted to lose all their cold and cool freshwater fisheries and in 17 states those fisheries will be halved [70]. Predicted national economic losses range from $\$ 80$ to $\$ 320$ million, depending on the predictive model used and the degree to which warm water fishery gains offset coldwater fishery losses. Jones et al. [71] predicted that the USA would lose $50 \%$ of its coldwater fisheries habitat by 2100 , with only western and northeastern mountainous areas supporting coldwater fisheries under the highest emission scenario. Under that scenario, coldwater fishing days would decline by 6.4 million, resulting in economic losses of $\$ 81$ million to $\$ 6.4$ billion depending on the emission scenario and discount rate. By altering ocean $\mathrm{pH}$, climate change is a serious potential threat to the zooplankton food base of marine recreational fishes and the ability of marine and estuarine mollusks and corals to fix 
calcium carbonate in their shells (AFS Web: http://fish eries.org/docs/policy_statements/policy_33f.pdf, accessed April 2014). Comte and Grenouillet [72] reported that French stream fish, including numerous species fished recreationally, have been unable to shift their ranges to higher elevations to keep pace with temperature changes from 1980 to 2009. Nonetheless, Tedesco et al. [73] noted that current and historical anthropogenic pressures account for more species extinctions than does predicted climate change.

\section{Conclusions}

Individuals and governments around the world value the conservation and sustainable use of recreational fisheries. In the USA and Europe that concern has led, respectively, to the Clean Water Act of 1972 with the goal of swimmable and fishable waters, and the Water Framework Directive with the goal of good water body condition and fisheries by 2015. Although we understand well how to manage sustainable recreational marine and freshwater fisheries, major historical, current and developing threats result from other demands on our lands and waters. Those threats either singly or together have markedly reduced once-substantial recreational fisheries on Great Lakes lake trout and lake sturgeon [74], Pacific salmon [75, 76], Atlantic salmon (WWF Web: http://awsassets.panda.org/downloads/sal mon2.pdf), and Atlantic cod (IUCN Web: http://www.sea fish.org/media/Publications/FS17_201003_IUCNRedList. pdf). Continued human population and economic growth drive those threats and thus fundamentally conflict with healthy and sustainable fisheries on those and many other species [2, 77-79].

Acknowledgments Yadan Liu invited me to present an earlier draft of this paper at the Third International Recreational Fisheries Forum in Xiamen, Fujian Province, China. Ian Winfield assisted manuscript preparation by sharing a draft of his recreational fishery manuscript with me and Sabrina Lovell provided valuable information regarding marine fisheries. Yumi Terashima invited me to submit this review manuscript to Fisheries Science and Tadashi Tokai suggested several helpful improvements. As its President, the American Fisheries Society supported my airfare to present this paper at the March 2014 annual meeting of the Japanese Society of Fishery Science in Hakodate, Hokkaido, Japan.

\section{Appendix 1}

Common recreational Atlantic Coast marine finfish fisheries.

Amberjack, pompano Seriola, Carangidae

Atlantic cod Gadus, Gadidae

Drum (black, red) Pogonias, Sciaenops, Sciaenidae
Black sea bass Centropristis, Serranidae

Bluefish Pomatomus, Pomatomidae

Bonefish Albula, Albulidae

Bonito Sarda, Scombridae

Dolphinfish Coryphaena, Coryphaenidae

Marlin (blue, white) Makaira, Tetrapturus,

Istiophoridae

Plaice Hippoglossoides, Pleuronectidae

Red snapper Lutjanus, Lutjanidae

Sailfish Istiophorus, Istiophoridae

Snook Centropomus, Centropomidae

Spotted sea trout, weakfish Cynoscion, Sciaenidae

Striped bass Morone, Moronidae

Summer flounder Paralichthys, Paralichthyidae

Swordfish Xiphias, Xiphiidae

Tarpon Megalops, Megalopidae

Tautog Tautoga, Labridae

Wahoo Acanthocybium, Scombridae

Yellowfin tuna Thunnus, Scombridae.

\section{Appendix 2}

Common recreational Atlantic Coast marine shellfish fisheries.

Clam (hardshell, quahog, razor, softshell, surf) Mercenaria, Veneridae; Ensis, Pharidae; Mya, Myidae; Spisula, Mactridae

Conch Lobatus, Strombidae

Crab (blue, stone) Callinectes, Portunidae; Menippe, Menippidae

Lobster (American, spiny) Homarus, Nephropidae; Panulirus, Palinuridae

Mussel Mytilus, Mytilidae

Oyster Crassostrea, Ostreidae

Scallop (bay, calico) Argopecten, Pectinidae

Whelk Busycon, Buccinidae.

\section{Appendix 3}

Common recreational Pacific Coast marine finfish fisheries.

Cabezon Scorpaenichthys, Cottidae

Dolphinfish Coryphaena, Coryphaenidae

Greenling Heagrammos, Hexagrammidae

Halibut Hippoglossus, Pleuronectidae

Lingcod Ophiodon, Hexagrammidae

Pacific herring Clupea, Clupeidae

Redtail surfperch Amphistichus, Embiotocidae

Rockfish (black, black-and-yellow, blue, brown, calico, china, copper, gopher, grass, kelp, olive, treefish) Sebastes, Sebastidae

Starry flounder Platichthys, Pleuronectidae 
Tuna (albacore, yellowfin, yellowtail) Thunnus, Scombridae.

\section{Appendix 4}

Common recreational Pacific Coast marine shellfish fisheries.

Clams (butter, littleneck, gaper, razor, softshell) Saxidomus, Prothothaca, Veneridae; Treusus, Mactridae; Siliqua, Pharidae; Mya, Myidae;

Crab (Dungeness, red rock) Metacarcinus, Cancer, Cancridae

Mussel Mytilus, Mytilidae

Squid Loglio, Logliginidae.

\section{Appendix 5}

Common recreational inland coldwater fisheries.

American shad Alosa, Clupeidae

Salmon (Atlantic, coho, Chinook, sockeye) Salmo, Oncorhynchus, Salmonidae

Sturgeon (lake, white) Acipenser, Acipenseridae

Trout (brook, brown, cutthroat, lake, rainbow) Salvelinus, Salmo, Oncorhynchus, Salmonidae.

\section{Appendix 6}

Common recreational inland warmwater fisheries.

Black bass (largemouth, redeye, smallmouth, spotted)

Micropterus, Centrarchidae

Bullhead (black, brown, yellow) Ameiurus, Ictaluridae

Catfish (blue, channel, flathead) Ictalurus, Pylodictus, Ictaluridae

Crappie (black, white) Pomoxis, Centrarchidae

Pike (northern, muskellunge) Esox, Esocidae

Rock bass (Roanoak, rock, shadow) Ambloplites, Centrarchidae

Sunfish (bluegill, longear, orangespotted, pumpkinseed, redbreast, redear, spotted) Lepomis, Centrarchidae

Temperate bass (striped, yellow, white, white perch) Morone, Moronidae

Walleye, sauger Sander, Percidae

Yellow perch Perca, Percidae.

\section{References}

1. Brownscombe JW, Bower SD, Bowden W, Nowell L, Midwood JD, Johnson N, Cooke SJ (2014) Canadian recreational fisheries:
35 years of social, biological, and economic dynamics from a national survey. Fisheries 39:251-260

2. Limburg KE, Hughes RM, Jackson DC, Czech B (2011) Population increase, economic growth, and fish conservation: collision course or savvy stewardship? Fisheries 36:27-35

3. Shapiro MH, Holdsworth S, Paulsen SG (2008) The need to assess the condition of aquatic resources in the US. J N Am Benthol Soc 27:808-811

4. Paulsen SG, Mayio A, Peck DV, Stoddard JL, Tarquinio E, Holdsworth SM, Van Sickle J, Yuan LL, Hawkins CP, Herlihy A, Kaufmann PR, Barbour MT, Larsen DP, Olsen AR (2008) Condition of stream ecosystems in the US: an overview of the first national assessment. J N Am Benthol Soc 27:812-821

5. USEPA (US Environmental Protection Agency) (2013) National rivers and streams assessment 2008-2009: a collaborative survey. EPA/841/D-13/001.Office of Wetlands, Oceans and Watersheds and Office of Research and Development, Washington, DC

6. USEPA (US Environmental Protection Agency) (2009) National lakes assessment: a collaborative survey of the Nation's lakes. EPA/841/R-09/001.Office of Water and Office of Research and Development, Washington, DC

7. Hubert WA, Quist MC (eds) (2010) Inland fisheries management in North America. American Fisheries Society, Bethesda

8. Allen MS, Hightower JE (2010) Fish population dynamics: mortality, growth, and recruitment. In: Hubert WA, Quist MC (eds) Inland fisheries management in North America. American Fisheries Society, Bethesda, pp 43-80

9. Isermann DA, Paukert CP (2010) Regulating harvest. In: Hubert WA, Quist MC (eds) Inland fisheries management in North America. American Fisheries Society, Bethesda, pp 185-212

10. Trushenski J, Flagg T, Kohler C (2010) Use of hatchery fish for conservation, restoration, and enhancement of fisheries. In: Hubert WA, Quist MC (eds) Inland fisheries management in North America. American Fisheries Society, Bethesda, pp 261-294

11. Pegg MA, Chick JH (2010) Habitat improvement in altered systems. In: Hubert WA, Quist MC (eds) Inland fisheries management in North America. American Fisheries Society, Bethesda, pp 295-394

12. Bonar S, Hubert W, Willis D (eds) (2009) Standard methods for sampling North American freshwater fishes. American Fisheries Society, Bethesda

13. Kwak TJ, Freeman MC (2010) Assessment and management of ecological integrity. In: Hubert WA, Quist MC (eds) Inland fisheries management in North America. American Fisheries Society, Bethesda, pp 353-394

14. Pope KL, Lochmann SE, Young MK (2010) Methods for assessing fish populations. In: Hubert WA, Quist MC (eds) Inland fisheries management in North America. American Fisheries Society, Bethesda, pp 325-352

15. Chipps SR, Graeb BDS (2010) Ecology and management of lake food webs. In: Hubert WA, Quist MC (eds) Inland fisheries management in North America. American Fisheries Society, Bethesda, pp 395-424

16. Schinegger R, Trautwein C, Melcher A, Schmutz S (2012) Multiple human pressures and their spatial patterns in European running waters. Water Environ J 26:261-273

17. Mebane CA, Maret TR, Hughes RM (2003) An index of biological integrity (IBI) for Pacific Northwest rivers. Trans Am Fish Soc 132:239-261

18. Snyder CD, Young JA, Villella R, Lemarie DP (2003) Influences of upland and riparian land use patterns on stream biotic integrity. Landscape Ecol 18:647-664

19. Wang L, Lyons J, Kanehl P (2003) Impacts of urban land cover on trout streams in Wisconsin and Minnesota. Trans Am Fish Soc $132: 825-839$ 
20. Stranko SA, Hilderbrand RH, Morgan RP II, Staley MW, Becker AJ, Roseberry-Lincoln A, Perry ES, Jacobson PT (2008) Brook trout declines with land cover and temperature changes in Maryland. N Am J Fish Manag 28:1223-1232

21. Trautwein C, Schinegger R, Schmutz S (2012) Cumulative effects of land use on fish metrics in different types of running waters in Austria. Aquat Sci 74:329-341

22. Woody CA, Hughes RM, Wagner EJ, Quinn TP, Roulsen LH, Martin LM, Griswold K (2010) The US general mining law of 1872: change is overdue. Fisheries 35:321-331

23. Roth NE, Allan JD, Erickson DL (1996) Landscape influences on stream biotic integrity assessed at multiple spatial scales. Landscape Ecol 11:141-156

24. Wang L, Lyons J, Kanehl P, Gatti R (1997) Influences of watershed land use on habitat quality and biotic integrity in Wisconsin streams. Fisheries 22(6):6-12

25. Van Sickle J, Baker J, Herlihy A, Bayley P, Gregory S, Haggerty P, Ashkenas L, Li J (2004) Projecting the biological condition of streams under alternative scenarios of human land use. Ecol Appl 14:368-380

26. Sály P, Takács P, Kiss I, Bíró P, Erős T (2011) The relative influence of spatial context and catchment- and site-scale environmental factors on stream fish assemblages in a human-modified landscape. Ecol Freshwat Fish 20:251-262

27. Marzin A, Verdonschot PFM, Pont D (2013) The relative influence of catchment, riparian corridor, and reach-scale anthropogenic pressures on fish and macroinvertebrate assemblages in French rivers. Hydrobiol 704:375-388

28. Macedo DR, Hughes RM, Ligeiro R, Ferreira WR, Castro M, Junqueira NT, Silva DRO, Firmiano KR, Kauffman PR, Pompeu PS, Callisto M (2014) The relative influence of catchment and site variables on fish and macroinvertebrate assemblage richness in cerrado biome streams. Landscape Ecol 29:1001-1016. doi:10. 1007/s10980-014-0036-9

29. Hughes RM, Wang L, Seelbach PW (eds) (2006) Landscape influences on stream habitat and biological assemblages. American Fisheries Society, Bethesda

30. Yeakley JA, Maas-Hebner KG, Hughes RM (eds) (2014) Wild salmonids in the urbanizing Pacific Northwest. Springer, New York

31. Stanford JA, Ward JV, Liss WJ, Frissell CA, Williams RN, Lichatowich JA, Coutant CC (1996) A general protocol for restoration of regulated rivers. Regul Rivers Res Manag 12:391-413

32. Poff NL, Allan JD, Bain MB, Karr JR, Prestegaard KL, Richter BD, Sparks RE, Stromberg JC (1997) The natural flow regime. Bioscience 47:769-784

33. Hughes RM, Rinne JN, Calamusso B (2005) Historical changes in large river fish assemblages of the Americas: a synthesis. In: Rinne JN, Hughes RM, Calamusso B (eds) Historical changes in large river fish assemblages of the Americas. American Fisheries Society, Bethesda, pp 603-612

34. Carlisle DM, Wolock DM, Meador MR (2011) Alteration of streamflow magnitudes and potential ecological consequences: a multiregional assessment. Front Ecol Environ 9:264-270

35. Sedell JR, Froggatt JL (1984) Importance of streamside forests to large rivers: the isolation of the Willamette River, Oregon, USA, from its floodplain by snagging and streamside forest removal. Verh Intl Verein Limnol 22:1828-1834

36. Walter RC, Merritts DJ (2008) Natural streams and the legacy of water-powered mills. Science 319:299-304

37. Kaufmann PR, Hughes RM (2006) Geomorphic and anthropogenic influences on fish and amphibians in Pacific Northwest coastal streams. In: Hughes RM, Wang L, Seelbach PW (eds) Landscape influences on stream habitat and biological assemblages. American Fisheries Society, Bethesda, pp 429-455
38. Bryce SA, Lomnicky GA, Kaufmann PR, McAllister LS, Ernst TL (2008) Development of biologically based sediment criteria in mountain streams of the western United States. N Am J Fish Manag 28:1714-1724

39. Jennings MJ, Bozek MA, Hatzenbeler GR, Emmons EE, Staggs MD (1999) Cumulative effects of incremental shoreline habitat modification on fish assemblages in north temperate lakes. N Am J Fish Manag 19:18-27

40. Sass GG, Kitchell JE, Carpenter SR, Hrabik TR, Marburg AE, Turner MG (2006) Fish community and food web responses to a whole-lake removal of coarse woody habitat. Fisheries 31:321-330

41. Whittier TR, Paulsen SG, Larsen DP, Peterson SA, Herlihy AT, Kaufmann PR (2002) Indicators of ecological stress and their extent in the population of northeastern lakes: a regional-scale assessment. Bioscience 52:235-247

42. Wagner T, Jubar AK, Bremigan MT (2006) Can habitat alteration and spring angling explain largemouth bass nest success? Trans Am Fish Soc 135:843-852

43. Kaufmann PR, Hughes RM, Whittier TR, Bryce SA, Paulsen SG (2014) Relevance of lake physical habitat assessment indices to fish and riparian birds. Lake Reserv Manag 30:177-191

44. Stahl LL, Snyder BD, Olsen AR, Pitt JL (2009) Contaminants in fish tissue from US lakes and reservoirs: a national probabilistic study. Environ Monitor Assess 150:3-19

45. Peterson SA, Van Sickle J, Herlihy AT, Hughes RM (2007) Mercury concentration in fish from streams and rivers throughout the western United States. Environ Sci Tech 41:58-65

46. Landers DH, Simonich SM, Jaffe D, Geiser L, Campbell DH, Schwindt A, Schreck C, Kent M, Hafner W, Taylor HE, Hageman K, Usenko S, Ackerman L, Schrlau J, Rose N, Blett T, Erway MM (2010) The Western Airborne Contaminant Assessment Project (WACAP): an interdisciplinary evaluation of the impacts of airborne contaminants in western U.S. National Parks. Environ Sci Tech 44:855-859

47. Rabalais NN, Turner RE, Scavia D (2002) Beyond science into policy: Gulf of Mexico hypoxia and the Mississippi River. Bioscience 52:129-142

48. Boyer EW, Goodale CL, Jaworski NA, Howarth RW (2002) Anthropogenic nitrogen sources and relationships to riverine nitrogen export in the northeastern USA. Biogeochemistry 57:37-169

49. Dodds WK, Bouska WW, Eitzmann JL, Pilger TJ, Pitts KL, Riley AJ, Schloesser JT, Thornbrugh DJ (2008) Eutrophication of U.S. freshwaters: analysis of potential economic damages. Environ Sci Tech 43:12-19

50. Lomnicky GA, Whittier TR, Hughes RM, Peck DV (2007) Distribution of nonnative aquatic vertebrates in western U.S. streams and rivers. N Am J Fish Manag 27:1082-1093

51. Sanderson BL, Barnas KA, Wargo Rub M (2009) Nonindigenous species of the Pacific Northwest: an overlooked risk to endangered salmon. Bioscience 59(3):245-256

52. Nickelson T (2003) The influence of hatchery coho salmon (Oncorhynchus kisutch) on the productivity of wild coho salmon populations in Oregon coastal basins. Can J Fish Aquat Sci 60:1050-1056

53. Nickelson TE, Solazzi MF, Johnson SL (1986) Use of hatchery coho salmon (Oncorhynchus kisutch) presmolts to rebuild wild populations in Oregon coastal streams. Can J Fish Aquat Sci 43:2443-2449

54. Pearsons TN (2008) Misconception, reality, and uncertainty about ecological interactions and risks between hatchery and wild salmonids. Fisheries 33:278-290

55. Naman SW, Sharpe CS (2012) Predation by hatchery yearling salmonids on wild subyearling salmonids in the freshwater 
environment: a review of studies, two cases histories, and implications for management. Environ Biol Fish 94:21-28

56. Tatara CP, Berejikian BA (2012) Mechanisms influencing competition between hatchery and wild juvenile anadromous Pacific salmonids in fresh water and their relative competitive abilities. Environ Biol Fish 94:7-19

57. Daly EA, Broduer RD, Fisher JP, Weitkamp LA, Teel DJ, Beckman BR (2012) Spatial and trophic overlap of marked and unmarked Columbia River Basin spring Chinook salmon during early marine residence with implications for competition between hatchery and naturally produced fish. Environ Biol Fish 94: $117-134$

58. Kaeriyama M, Seo H, Kudo H, Nagata M (2012) Perspectives on wild and hatchery salmon interactions at sea, potential climate effects on Japanese chum salmon, and the need for sustainable salmon fishery management reform in Japan. Environ Biol Fish 94:165-177

59. Naish KA, Taylor JE III, Levin PS, Quinn TP, Winton JR, Huppert D, Hilborn R (2008) An evaluation of the effects of conservation and fishery enhancement hatcheries on wild populations of salmon. Adv Mar Biol 53:61-194

60. Ruggerone GT, Agler BA, Nielsen JL (2012) Evidence for competition at sea between North Sound chum salmon and Asian hatchery chum salmon. Environ Biol Fish 94:149-163

61. Colborn T, vom Saal FS, Soto AM (1993) Development effects of endocrine-disrupting chemicals in wildlife and humans. Environ Health Persp 101:378-384

62. Tyler CR, Jobling S, Sumpter JP (1998) Endocrine disruption in wildlife: a critical review of the evidence. Crit Rev Toxicol 28:319-361

63. Hayes TB, Case P, Chui S, Chung D, Haeffele C, Haston K, Lee L, Mai VP, Marjuoa Y, Parker J, Tsui M (2006) Pesticide mixtures, endocrine disruption, and amphibian declines: are we underestimating the impact? Environ Health Persp 114(S-1): 40-50

64. Brown AR, Riddle AM, Winfield IJ, Fletcher JM, James JB (2005) Predicting the effects of endocrine disrupting chemicals on healthy and disease impacted populations of perch (Perca fluviatilis). Ecol Model 189:377-395

65. Crane M, Gross M, Matthiessen P, Ankley GT, Axford S, Bjerregaard P, Brown R, Chapman P, Dorgeloh M, Galay-Burgos M, Green J, Hazlerigg C, Janssen J, Lorenzen K, Parrott J, Rufli H, Schäfers C, Seki M, Stolzenberg H-C, van der Hoeven N, Vethaak D, Winfield IJ, Zok S, Wheeler J (2010) Multi-criteria decision analysis of test endpoints for detecting the effects of endocrine active substances in fish full life cycle tests. Integr Environ Assess Manag 6:378-389

66. Colborn T, Dumanosk D, Myers JP (1996) Our stolen future. Dutton, New York
67. Handy RD, Owen R, Valsami-Jones E (2008) The ecotoxicology of nanoparticles and nanomaterials: current status, knowledge gaps, challenges, and future needs. Ecotoxicol 17:315-325

68. Shaw BJ, Handy RD (2011) Physiological effects of nanoparticles on fish: a comparison of nanometals versus metal ions. Environ Int 37:1083-1097

69. Cedervall T, Hansson L-A, Lard M, Frohm B, Linse S (2012) Food chain transport of nanoparticles affects behaviour and fat metabolism in fish. PLoS One 7(2):e32254. doi:10.1371/journal. pone.0032254

70. Michaels G, O’Neal K, Humphrey J, Bell K, Camacho R, Funk R (1995) Ecological impacts from climate change: an economic analysis of freshwater recreational fishing EPA-230-R-95-004. Office of Policy Planning and Evaluation. USEPA, Washington

71. Jones R, Travers C, Rodgers C, Lazar B, English E, Lipton J, Vogel J, Strzepek K, Martinich J (2013) Climate change impacts on freshwater recreational fishing in the United States. Mitig Adapt Strateg Glob Change 18:731-758

72. Comte L, Grenouillet G (2013) Do stream fish track climate change? Assessing distribution shifts in recent decades. Ecography $36: 1-11$

73. Tedesco PA, Oberdorff T, Cornu J-F, Beauchard O, Brosse S, Dürr HH, Grenouillet G, Leprieur F, Tisseuil C, Zaiss R, Hugueny B (2013) A scenario for impacts of water availability loss due to climate change on riverine fish extinction rates. J Appl Ecol 50:1105-1115

74. Regier HA, Hughes RM, Gannon JE (2013) The lake sturgeon as survivor and integrative indicator of changes in stressed aquatic ecosystems in the Laurentian Basin. In: Dempsey D, Auer N (eds) The great lake sturgeon. Michigan State University Press, Lansing, pp 27-57

75. Nehlsen WJ, Williams JE, Lichatowich JA (1991) Pacific salmon at the crossroads: stocks at risk from California, Oregon, Idaho, and Washington. Fisheries 16(2):4-21

76. Gustafson RG, Waples RS, Myers JM, Weitkamp LA, Bryant GJ, Johnson OW, Hard JJ (2007) Pacific salmon extinctions: quantifying lost and remaining diversity. Cons Biol 21:1009-1020

77. Clausen R, York R (2008) Global biodiversity decline of marine and freshwater fish: a cross-national analysis of economic, demographic, and ecological influences. Soc Sci Res 37: $1310-1320$

78. Leprieur F, Beauchard O, Blanchet S, Oberdorff T, Brosse S (2008) Fish invasions in the world's river systems: when natural processes are blurred by human activities. PLoS Biol 6(2):e28

79. Czech B (2013) Supply shock: economic growth at the crossroads and the steady state solution. New Society Publishers, Gabriola Island 